\title{
Does Greater Community Involvement Mean More Parent-Teacher Interaction? Evidence from Seven Developing Countries
}

\author{
Mobarak Hossain \\ Department of Social Policy and Intervention \\ Nuffield College, University of Oxford
}

\begin{abstract}
Advocates for school autonomy and decentralisation argue that community involvement in school decisions would bring positive educational outcomes by increasing parent-teacher interaction. In this study, I investigate to what extent community involvement associates with parents-teacher meetings in seven developing countries using Programme for International Student for Development (PISA-D) data-2015. Employing OLS regression models, I find that the correlation between community engagement in various school activities and parent-teacher interaction is largely insignificant. Findings rather suggest that private ownership and, in some cases, higher instructional resources of schools are associated with increasing parent-teacher communication. These findings remain similar in several specifications suggesting that community involvement as part of decentralising the education sector should not be seen as a panacea to overcoming challenges in schools in developing countries.
\end{abstract}

Keywords. Community involvement; Parent-teacher interaction; School resources; School ownership; PISA-D; Developing countries

\section{Introduction}

School-based management (SBM), transferring decision-making authority to schools, has been a common policy suggestion in the developing world by development actors during the past few decades. It calls for more community and parental participation in school-decisions and greater school autonomy to bring service efficiency (Vavrus, 2005; Zajda, 2006). Beginning with structural adjustment policies (SAP) by the World Bank and International Monetary Fund (IMF), SBM has been implemented almost in every aid recipient country as part of the policy to 
decentralise the education and other service sectors. This neoliberal management paradigm is also known as new public management (NPM) with a business-like approach to delivering public services (Meier \& O'Toole Jr, 2003).

The central tenet of SBM is community involvement in school management and decisionmaking processes, where 'community' refers to parents and members in the larger community such as leaders in local social, cultural and political institutions. This calls for more democratic practices in deciding school affairs where parents and local stakeholders will not be considered outsiders, rather a true part of the school community (Gordon \& Louis, 2009).

While the notion of community involvement may not be new in the global South, its renewed functions under SBM solidify the neoliberal ethos of business principles in running public schools. SBM advocates argue that involving communities in school activities, planning and decisions would likely empower parents to communicate with teachers potentially leading to positively affecting students' achievement (Barrera-Osorio et al., 2009). However, past research finds that parent-teacher face-to-face interaction leads to increased learning achievement (Islam, 2019), as opposed to communal meeting with school (Avvisati et al., 2014).

SBM promoters also believe that community involvement will help address the needs of the poorest by empowering grassroots population rather than simply putting more resources (Barrera-Osorio et al., 2009). This view goes against recent evidence that school resources are important determinants of achievement inequality in developing countries (Gruijters \& Behrman, 2020).

Critics warn that this efficiency and result-driven management paradigm does not focus on mitigating social inequalities. It is rather concerned about the overall performance of the education sector (Vermeulen, 2018). Notably, this 'business-model' considers parents as "clients" (Barrera- 
Osorio et al., 2009, p. 2), which has a universal notion of favouring one group over another based on fulfilling service providers' criteria. This may systematically exclude some parents from decisions because of social disadvantages. In other words, SBM overlooks structural barriers parents from disadvantaged backgrounds may face to participate in school decisions and takes it that establishment of another layer of governance in schools will incentivise everyone to play a role in decision-making.

Additionally, evidence from some developing countries suggests that the clientelist nature of local and school politics and a strong presence of informal governance in many developing countries have not resulted in welcoming parents in school decisions (e.g., Essuman \& Akyeampong, 2011). This is discussed more in the next section. Nonetheless, evidence is scarce examining whether SBM leads to greater parent-teacher interaction in the context of low- and middle-income countries. Research in this area typically examines the direct effect of community engagement on students' learning achievement. For instance, Barnett's (2013) study on Malawi finds that community involvement explains a small size of variation in pupils' reading and maths scores while its effects remain mixed. However, as proponents argue, the immediate result of community involvement is to encourage a participatory environment, which would supposedly push marginalised parents to interact with teachers about their children's educational progress.

Thus, taking into account this research gap, this study enquires - does community involvement in school in the era of SBM increase more parent-teacher personal interaction in developing countries? I investigate this on seven developing countries-Ecuador, Guatemala, Honduras, Paraguay, Cambodia, Senegal and Zambia-by using Programme for International Student Assessment for Development (PISA-D) data 2015 (OECD, n.d.). The diverse case 
selection is also a major contribution of this study which would enable us to see whether the stated effect of community involvement similar or dissimilar across countries.

\section{Theoretical Overview}

\subsection{Linking community involvement to parent-teacher interaction}

The central point of SBM is to strengthen the school committee by engaging local stakeholders including parents, teachers and social representatives in decision-making. In doing so, SBM aims to mobilise local resources such as increasing parents' and communities' contribution to the budget and developing infrastructures. This neoliberal paradigm calls for efficient governance of schools while minimising costs and maximising customers' or parents' satisfaction (Ball \& Youdell, 2009; Kowalczyk \& Jakubczak, 2014; Leithwood \& Menzies, 1998; Maroy, 2009; Tolofari, 2005).

Advocates argue that SBM, a cost-sharing mechanism initiated by SAP, empowers parents, especially those in hard-to-reach areas, to participate in decision-making and monitoring school performance (Gertler et al., 2006; World Bank, 2007). Barrera-Osorio et al. (2009) claim that SBM aims to bring authority to the local level closer to people which supposedly creates a strong and mutual accountability system between schools and local communities. This short route of accountability will supposedly enable parents from all social strata to point out the learning needs of their children. "Consequently, students' learning achievement and other outcomes can be expected to improve because stakeholders at the school level can monitor school personnel, work to improve student evaluations, ensure a closer match between school needs and policies, and use resources more efficiently" (Barrera-Osorio et al., 2009, p. 26). 
There is a strong notion of rationality that creating a platform will bring together people from all social spectrums who will then contribute to decisions equally according to their needs. However, this view disregards the contextual barriers such as socioeconomic and family background, and informal governance including partisan and clientelist local politics that may hinder the functioning of SBM. Furthermore, the practice of 'participation' in liberal democracies may not fit well in the context of developing countries. This, eventually, may not benefit any social groups at all. Or even if we take that SBM leads to more parent-teacher interaction, our knowledge is limited to what extent it depends on school characteristics such as resources.

Past research from developing countries suggests that excessive informal governance and partisan local politics in school committees keep marginalised people away from participating in decision-making or other forms of contribution (Beteille, 2009; Kingdon et al., 2014; Nishimura, 2017). Joshi (2014) finds that because of political interference in public schools, parents in Nepal prefer sending children to private schools. The study argues that politics in school management committees together with teachers' negligence negatively affect the learning environment. But why are not these neo-liberal schemes aiming at creating better governance able to replace illiberal practices? According to Essuman and Akyeampong (2011), the projected outcomes of SBM by international actors do not change local realities in developing countries. Their research in rural Ghana concluded that school management committees (SMCs) have been occupied by different local political actors and kept no space for community participation.

Additionally, it is often argued that in some developed countries such as Finland, school autonomy has contributed to exemplary success in terms of increasing equity of access and better learning achievements (Uljens et al., 2016). So, it might work as well in developing countries. However, social trust and a common understanding of mutual responsibilities have been the 
catalysts of this success (Sahlberg, 2010). But as just discussed, these conditions may not be present in the institutional culture of low-income countries in the presence of a clientelist relationship between superiors and subordinates, weak institutional capacity, and frequent irregularities.

Because of these structural challenges, strengthening SBM by community involvement may not matter in increasing parent-teacher interaction as much as school resources and parents' background. Since between-school achievement inequality in many developing countries is more prevalent than within-school or between-student inequality (Gruijters \& Behrman, 2020), interactive communication may depend on more school characteristics such as higher resources.

\subsection{Why parent-teacher interaction?}

SBM advocates believe that community participation in school decisions can improve students' learning achievement by empowering local people, especially parents. However, the learning progress mechanism of SBM is not quite clear. It is more plausible that learning improvement can happen through parent-teacher interaction. SBM promises to strengthen this tie. Fullan and Watson (2000) contend that SBM-related activities are not meant to be an end result and may not automatically improve learning outcomes unless schools already have a strong culture of parent-teacher communication. Parent-teacher communication may engage aspects that are directly related to the academic progress of children such as their learning progress, attitudes and behaviour towards truancy and schools' disciplinary rules (World Bank, 2007).

Empirical evidence also suggests that one-to-one individualised communication between parents and teachers is a core element for learning improvement. Islam (2019) finds that regularly scheduled face-to-face meetings between parents and teachers increased test scores of students in rural schools in Bangladesh. In this type of personalised pre-scheduled meetings, it is easier to 
monitor whether some parents are being absent, which would be hard to observe in SBM-initiated generic 'community' participatory mechanism. In an experiment in deprived schools in France, Avvisati et al. (2014) did not see any improvement in test score as a result of more parental involvement in school meetings, unlike personalised communication. However, they experienced some development in students' behaviour and disciplinary compliance.

Furthermore, at a more basic level, parental involvement is not even a well-developed concept in many developing countries. Researchers also contend that parental involvement cannot be a substitute for school quality such as basic infrastructures and resources, which schools in many low-income countries lack (Kim, 2018).

\subsection{Community involvement in the study settings}

To address the research puzzle explained, I use Programme for International Student Assessment for Development (PISA-D) data on seven low- and lower-middle-income countries, according to the classification of the World Bank (World Bank, n.d.-b). Countries are-Cambodia from Southeast Asia; Ecuador, Honduras, Guatemala and Paraguay from Latin America; and Senegal and Zambia from sub-Saharan Africa. These countries are eligible to receive Official Development Aid (ODA) (Organisation for Economic Co-operation and Development [OECD], 2015a) and, thus, have received assistance in the forms of grants and loans from development partners including the World Bank and IMF.

Virtually, all these countries have experienced the implementation of decentralisation projects, in which the World Bank has been the major player. My research on all available World Bank project documents covering primary and secondary education in the selected countries also suggests so. The key elements in decentralisation schemes have been to create or strengthen school level decentralisation and community participation through SBM. For instance, in Cambodia, a 
total of six projects addressing primary and secondary education have included components about the devolution of responsibilities to the school level and community participation. Both systemlevel, educational administration at sub-national levels, and school-level decentralisation are still being actively implemented in Senegal, Zambia, Cambodia and Ecuador (see Table 1 for details). This list merely shows the magnitude of efforts that have been channelled for SBM reforms. I do not intend to assess the impact of these reforms as this is beyond the scope of this paper.

SBM components in the World Bank projects have typically included issues such as establishing SMCs; community participation in preparing school plans and in planning budget and building schools; school-based teacher training; leadership development of school principals, among others. Not surprisingly, the project components also look quite alike.

These projects are, however, not an exhaustive list as other development actors including UNESCO and regional development banks have also promoted the neoliberal reform package of SBM and school-level decentralisation. For instance, Ganimian (2016) report that since the beginning of the 1990s, Honduras and Guatemala have increasingly adopted SBM allowing communities to make school decisions. Although slightly later, the adoption of SBM in the Cambodian education sector has similarly been notable so that parents can play a major role in school meetings (Shoraku, 2009). Research also suggests that SBM reforms in sub-Saharan Africa including Zambia and Senegal accompanied democratisation or popular elections at the local level (Naidoo, 2005). Despite the diversity of methods SBM has been introduced through, the common element is the participation of parents and the local community in key decisions.

In spite of this 'vigorous' exportation of SBM policies to decentralise the education sector in many developing countries (Maroy, 2009), comparative empirical research in this area remains very negligible. I aim to fill this gap using the conceptual framework elaborated in the next section. 


\section{Table 1}

World Bank projects implementing decentralisation projects in primary and secondary education at school and various local government levels in the seven selected countries

\begin{tabular}{|c|c|c|c|c|c|c|c|c|}
\hline Decentralisation level & Cambodia & Ecuador & Guatemala & Honduras & Paraguay & Senegal & Zambia & Total \\
\hline Schools and communities & 6 & 1 & 2 & 5 & 2 & 7 & 3 & 26 \\
\hline $\begin{array}{l}\text { Local government/Educational } \\
\text { administration, schools and communities }\end{array}$ & & & 1 & & & 4 & & 5 \\
\hline Educational administration & 2 & 1 & 3 & 5 & 3 & 6 & 5 & 25 \\
\hline No focus on decentralisation & & 2 & 4 & 1 & 1 & 1 & 4 & 13 \\
\hline $\begin{array}{r}\text { Decentralisation accompanying total } \\
\text { basic education projects }\end{array}$ & 6 out of 6 & 2 out of 4 & 4 out of 8 & 7 out of 8 & 4 out of 5 & 7 out of 8 & 6 out of 9 & \\
\hline First basic education project & 2005 & 1968 & 1968 & 1973 & 1972 & 1975 & 1969 & \\
\hline Decentralisation starting year & 2005 & 2015 & 1988 & 1978 & 1976 & 1986 & 1992 & \\
\hline SBM/Community participation started & Ditto & Ditto & Ditto & 2001 & 1995 & Ditto & Ditto & \\
\hline Current decentralisation project status & Active & Active & Last-2020 & Last-2013 & Last-2009 & Active & Active & \\
\hline
\end{tabular}

Notes. Decentralisation level indicates the focus of the projects on each level, either combined with one or several levels or alone. The first three rows are on communities, schools or both together. To prepare this dataset, I have conducted extensive research on all available World Bank project/operation documents on primary and secondary education on the organisation's website (World Bank, n.d.-a).

Source. Author's data based on World Bank (n.d.-a). 


\section{Determinants of parent-teacher interaction: a conceptual framework}

Existing theories regarding how community participation in decentralised educational systems may affect parent-teacher relationship are mostly based on developed countries as SBM reform in developing countries is western emerged (Maroy, 2009). This is not to say that community engagement with schools did not exist in developing countries before. But the way it has been institutionalised and prioritised over school resources and other inputs is quite new and somewhat foreign in many of these countries. Nonetheless, insights from existing literature, especially on how community participation affects disadvantaged parents, may be relevant.

Some researchers suggest that the democratic environment in school triggered by SBM increases substantive parental involvement in school decisions going beyond traditional contributions such as fundraising (Reitzug \& Cross, 1995). Cautioning about this claim, Briggs and Wohlstetter (2003) maintain that parents' participation in SBM becomes symbolic when the authority is not widely dispersed and concentrated in the hands of a few. This can happen more in the context of low-income countries where the power structure has traditionally been centralised and SBM or the practice of community involvement has been newly introduced. Fullan and Watson (2000) argue that SBM is a cultural change and even western countries with a long tradition of local autonomy struggle to fully implement it. In developing countries, SBM appears to be a radical change and it will take time to adapt to these changes. Their view is that SBM or community participation will not necessarily lead to better results unless the "majority of teachers engage the majority of parents" (Fullan \& Watson, 2000, p. 466). In other words, parent-teacher communication is vital for the ultimate better outcomes. 


\section{Figure 1}

Conceptual framework

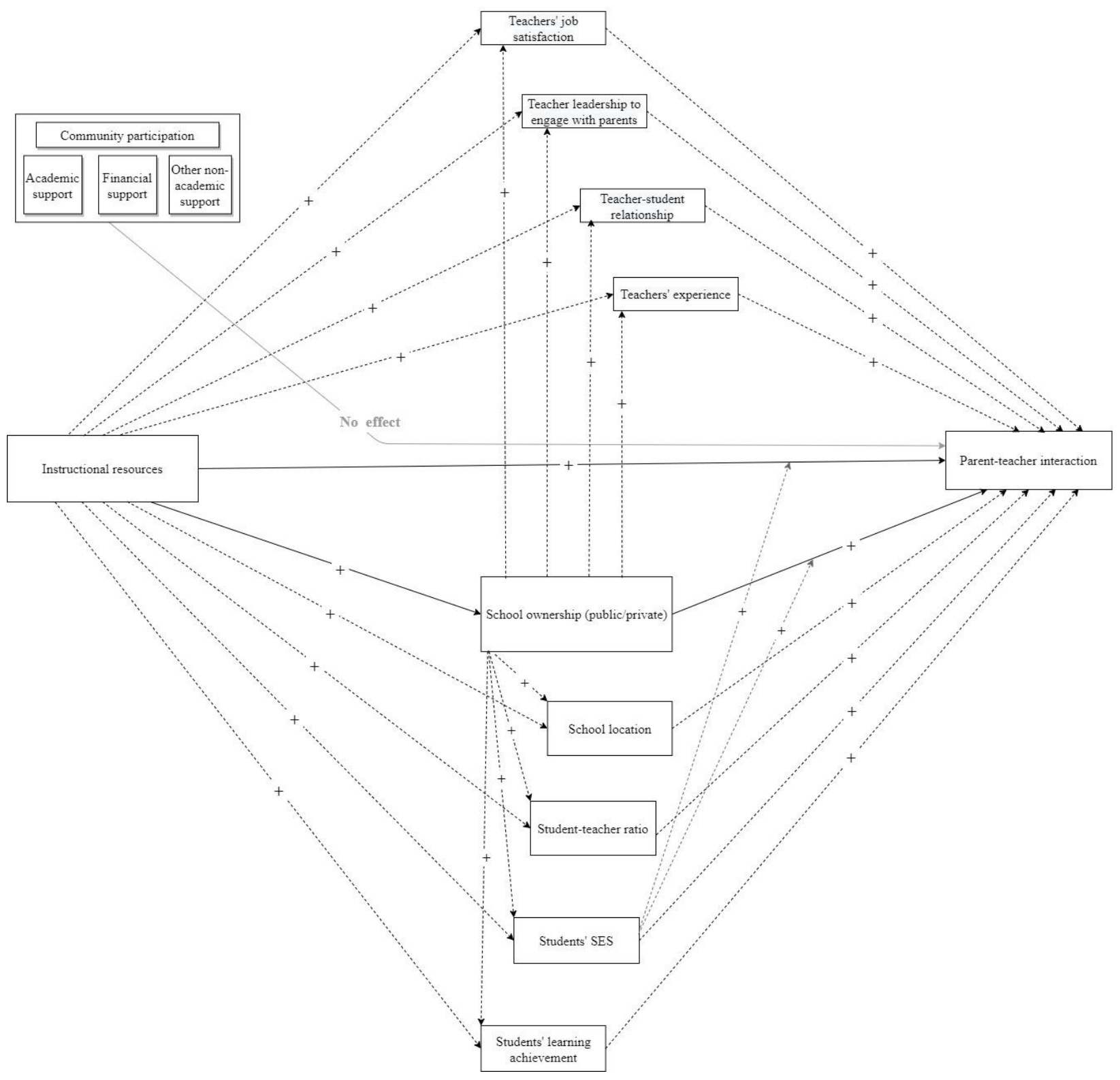

Note. + denotes a positive relationship.

As aforementioned, school decentralisation advocates such as Barrera-Osorio et al. (2009) argue that community involvement through SBM will empower parents from various social strata via a new accountability system. But, researchers including Beck and Murphy (1999) argue that participation of poor and minority parents in decentralised systems with power devolution remains 
quite similar to that of centralised systems. In a nutshell, literature drawn from developed countries indicates that disadvantaged parents may not benefit much from a scheme like community participation.

However, in developing countries, the disadvantage in parent-teacher meetings may arise more from school characteristics. The role of individual socioeconomic status (SES) in predicting students' learning achievement is less vital in low-income countries, which has been consistently reported in the last few decades (Chiu, 2010; Gruijters \& Behrman, 2020; Heyneman \& Loxley, 1983). As shown in Figure 1 in the conceptual framework, I assume that this will also hold in the case of parent-teacher interaction as well-resourced schools would have more qualified teachers that would be supposedly inclined to discuss students' progress with parents. Hence, resources, especially related to instructions, may play a stronger role to bring parents closer to teachers than having local communities involved in school activities.

The expected negligible role of communities is also because the managerial and profitdriven culture of this neoliberal reform has focused on results, efficiency, and individual success rather than universal service delivery (Andrews \& Van de Walle, 2013). Hence, communities may engage with schools differently depending on their socioeconomic circumstances which may potentially induce between-school inequality. I, therefore, do not assume that community participation would have a direct effect on parent-teacher interaction.

One may argue that SES and school resources may mediate community involvement's relationship with parent-teacher interaction since lower-SES students would be more likely to attend schools in need of community support. This argument may not hold for two reasons. First, I define community involvement using a comprehensive list of indicators covering financial support, academic support, and other non-academic support such as students' welfare and ensuring 
an inclusive learning environment. Most of these issues have been considered in Barnett (2013) when defining community involvement. The diversity of component selection means schools from a wide range of background would have some ways of involving communities. Second, as shown in Table 1, reforms focusing on SBM and community participation by the World Bank (and supposedly by other donors) have been implemented in schools across the selected countries, not any selected sub-sample of schools.

Alongside school resources, I also assume that private schools may have a higher frequency of meeting requests given that they tend to be more autonomously run and may create more scope for parent-teacher interaction. However, there are heterogeneous private schooling systems in lowincome countries including low and high fees, religious and secular schools, to mention a few. This means instructional resources will widely vary. Despite these differences, private schools are more likely to have more instructional resources by collecting fees which makes teachers more accountable towards parents or 'clients' as SBM promoters term. Thus, as Figure 1 suggests, I expect that school ownership would have a mediation effect on the relationship between instructional resources and parent-teacher interaction.

Similarly, school location, that is, urban or rural, may have a mediation effect on the relationship of instructional resources and school ownership since urban areas may likely have better resourced and private schools. Furthermore, the pupil-teacher ratio may also mediate the relationship of these two factors as having smaller groups of students would enable teachers to interact more with parents. Well-resourced and private schools are more likely to keep this ratio small.

Apart from these school factors, as shown in the lower part of Figure 1, students' SES may mediate the effect of school resources and ownership since wealthier students may likely attend 
private and well-funded schools. This would enable higher-SES parents to communicate with teachers by having more informational and monetary capitals while lower-SES parents may not do so by lacking appropriate resources. SES may also moderate the relationship of resources and ownership with parental engagement as the effects of both these factors may vary by higher- and lower-SES groups. Besides, students' learning achievement may also mediate the relationship as high achievers may attend wealthy and private schools and more likely to interact with teachers.

Additionally, as shown on the upper side of Figure 1, teachers' characteristics may as well mediate the effects of the main predictors, which include how experienced teachers are, their relationship with students, leadership, and job satisfaction. Both well-off and private schools may have a higher proportion of more experienced and student-oriented teachers who also have better leadership traits and are eventually more satisfied with their job. Thus, teachers' professional and academic background will likely play a key role in how well they interact with parents.

\section{Method}

\subsection{Data}

I use PISA-D data 2015 from seven developing countries from Latin America, sub-Saharan Africa and East Asia. Starting from 2000, PISA assesses mathematics, reading and science skills of 15-year-olds in OECD and non-OECD countries every three years. PISA for development was the first pilot project conducted in 2015 on seven low- and lower-middle-income countries (OECD, 2015b). The age group (15 years old) in the dataset mostly comprises lower-secondary students (grades 7-10) but also includes around 11 percent of pupils from upper-secondary level (see Appendix A1 for summary statistics). Since SBM-induced community involvement has been 
implemented throughout primary and secondary schools, the selected age group is suitable for the study, which will capture the scenario of this management paradigm at the secondary level.

\subsection{Measures}

\subsubsection{Parent demand for meetings on child's progress}

This outcome variable captures whether parents/family members ask for personal meetings with teachers to discuss the progress of their children, reported by teachers in a questionnaire ${ }^{1}$. The variable is ordinal consisting of four ordered categories - the frequency of meeting demand is 1) never or almost never; 2) sometimes; 3) often; and 4) always or almost always. Meeting demand, instead of actual meetings, is a better predictor for this study since it shows parents' enthusiasm to interact with teachers and implicitly the openness of the school towards such demands, which SMB promises to augment. However, as noticed in Table A2 in the appendix, categories 3 and 4 in general, but especially in Cambodia, Senegal and Zambia, have fewer observations.

To address this issue, I create a continuous indicator of community involvement in two steps. First, since the indicator was originally measured at the teacher level (there are a number of teachers in a school), I first create a binary indicator: a) the meeting demand in a school does not exist by category 1 , and b) teachers in a school receive meeting demand- sometimes, often or always by categories 2 to 4 . Second, I then calculate the percentage of teachers getting meeting demand from parents in a school, which is the final measure of the variable. I calculate the school mean of this variable and merge school level variables with student-level predictors. ${ }^{2}$

\subsubsection{Community involvement}

In PISA-D, there are eight binary indicators of whether local community members participate in a range of school decisions and activities, as reported by school principals in response 
to a questionnaire. I create a combined variable with four categories from these indicators as explained in the following.

The indicators are: whether community members or organisations contribute to school 1) by building and 2) maintaining school facilities such as classrooms or teachers' houses; 3) by taking care of school grounds and fences; 4) by constructing or repairing the furniture or equipment; 5) by teaching when teachers are absent; 6) by assisting teachers in addressing the needs of students with disabilities;7) by organising sports activities or school trips; and 8) by assisting with preparation and distribution of school meals. The variables are coded as 0 indicating no involvement and 1 denoting yes. These measures include local community's engagement in three broad areas: b) financial support covered by indicators 1 to 4 a) academic support by teaching and providing meals; and c) welfare support by arranging extracurricular activities and disability support. These are the main interests of this study as mentioned in the conceptual framework. The indicators also reflect efforts for local resource mobilisation through the community's active contribution which are considered to be some of the important elements of community participation in SBM (Uemura, 1999). My research on World Bank projects in the selected countries suggests a strong focus on mobilising community resources through SBM (World Bank, n.d.-a).

However, some of these indicators have skewed distribution as these are rarely practised (see Table A2 in the appendix). This may mean the type of community involvement may vary by school background. Considering this factor, I combine all these indicators to create a single index of the number of community involvement activities a school perform out of total eight. Nevertheless, there are few schools that involve communities in more than five activities in most of the countries. To address this skewness in distribution, I divide the combined indicator into four 
dummy categories: i) 0 when no community involvement, ii) 1 indicating low involvement, iii) 2 and 3 denoting mid-level, and iv) 4 to 8 signifying high-level involvement.

\subsubsection{Instructional Resources}

This is a continuous measure comprised of 38 items related to schools' instructional resources including writing board, chairs and desks for students, library, TV, radio, textbooks, dictionary, computer room, science lab, computer, art room, gym, among others. The variable was constructed using item response theory (OECD, n.d.).

\subsubsection{Private school}

This is a dummy variable indicating either a school is private or public. This is originally coded as to whether a school is (a) private independent, (b) private but government-dependent or (c) public. I combine categories a and b as 'private' as there are very few or no schools (in Senegal and Zambia) under the 'private but government-dependent' category.

\subsubsection{SES}

To measure SES, I use the continuous and composite index of economic, social and cultural status (ESCS) of children from PISA-D dataset. This variable combines parents' occupation, education and household resources such as books, desk, reading room, computer, TV, radio, refrigerator and cars, among other items.

\subsubsection{Other controls}

Student-level controls in the study include students' sex and the grade level. I do not control for age as it is likely to be collinear with grade. Moreover, the achievement score in maths is a continuous variable with a mean of ranging from around 276 for Zambia to 377 for Ecuador. The location of schools is a school-level dummy variable indicating urban or rural. Originally, this has five categories: a school is located in a) a village, b) a small town, c) a town, d) a city, and e) big 
city. Since some categories have very few schools, I combine categories a and b indicating rural and the latter three as urban schools. Another school control is the student-teacher ratio which is a continuous variable indicating the number of pupils per teacher.

In addition, teacher controls include their teaching experience in years, a continuous index of teachers' relationship with students, a continuous index on teachers' view about transformational leadership, and their job satisfaction, which is also a continuous indicator. The teacher-level variables are aggregated at the school level to merge with student-level variables (see Appendix A1).

\subsection{Analytical Approach}

To examine the association between community involvement in schools' daily activities and demand for parent-teacher interaction, I specify the following ordinary least squares (OLS) regression model. Here,

$$
P_{c}=\delta+\beta C_{c}+\alpha R_{c}+\gamma O_{c}+\phi \boldsymbol{H}_{c}+\psi \boldsymbol{S}_{s c}+r_{s c}
$$

$P_{c}$ is the observed level of demand by parents to hold meetings with teachers about children's progress in $\operatorname{school}_{c}$, in terms of the percentage of teachers receiving the request. $\delta$ is an intercept, $\beta$ is the coefficient on the level of community involvement $C_{c}, \alpha$ is the coefficient on school instructional resources $R_{c}, \gamma$ is the coefficient on school ownership $O_{c}$, and $\phi$ is a vector of coefficients on school and the school mean of teacher-level controls $\boldsymbol{H}_{c}$-location and the four variables about teachers' characteristics as listed in the variable section. $\psi$ is a vector of coefficients on controls at student level $\boldsymbol{S}$ (that is, students ${ }_{s}$ in school c) such as SES, grade, sex and their maths score. $r_{s c}$ is an error term. I estimate this regression equation on each country 
separately as this allows to examine the differences in effects across countries. I account for final student survey weights to estimate all the models.

Moreover, to account for moderation effects of SES on the relationship of school resources and ownership, I fit equation 2. Here,

$$
P_{c}=\delta+\beta C_{c}+\alpha R_{c}+\gamma O_{c}+\mu W_{s c}+\lambda R_{c} \cdot W_{s c}+\theta O_{c} \cdot W_{s c}+\phi \boldsymbol{H}_{c}+\psi \boldsymbol{\boldsymbol { S } _ { s c }}+r_{s c}
$$

the additional parameters are the interaction of school resources $R_{c}$ and ownership $O_{c}$ with students' SES $W_{s c}$ where the corresponding coefficients are $\lambda$ and $\theta$, respectively.

Since I consider a range of predictors from student, school and teacher questionnaires, some variables have missing values. This would lead to losing valuable information from the analysis. To tackle this issue, I impute the independent variables. As shown in Table A1 in the appendix, some variables on background characteristics have missing observations, which are, with a few exceptions, less than 6 percent. However, community involvement does not have any missing values for the observations in the study. To ensure that the imputed data are not driving the results, I use a dummy indicator for each variable with missing values in the regression models where 1 indicates imputed data and 0 denotes otherwise. Hanushek and colleagues (2013) apply this technique in their research using PISA data. I also present results in Figure A1 in the appendix without adding dummies to show whether they influence the findings. Additionally, this study does not suggest any causal inference by words such as 'effect' or 'influence', which are used merely in the statistical sense.

Since the dependent variable in this study is bounded between 0 and 1 representing a continuous proportion, one may argue that the variance in the data is heteroskedastic for which linear models may not be appropriate. To address this issue, I run generalised linear models (GLM) 
with logit function as robustness checks. I briefly discuss the results from GLM models in the findings section.

\section{Findings}

As descriptive statistics in Table A1 in the appendix suggests, the frequency of meeting demand received by the percentage of teachers from parents about students' progress varies across countries. Similarly, the level of community involvement in various activities also differs. This variance allows us to explore to what extent the effect of community involvement and other factors, as discussed, also varies by country.

\subsection{Mediation effect: school characteristics and parent-teacher meetings}

To first examine the association between community engagement and parent-teacher meeting request about student matters, I only add the community involvement variable to the model. As the 'no control' model in Figure 2 suggests, the coefficient for community involvement is not significant in any of the countries. Among the four categories, the base category in the plot is 'no community involvement'. Similarly, when I add all variables including instructional resources except for school ownership, community involvement coefficient remains still nonsignificant in all countries. In this 'without school ownership' model, instructional resources variable appears significant in most of the countries apart from Senegal and Zambia. I also present the results from this model in Table A3 in the appendix with all covariates.

However, since my initial hypothesis was that the relationship between resources and parent-teacher interaction would be mediated by school ownership, among other factors as explained, I add ownership variable to the third model to examine this. As 'all variable' or model 3 in Figure 2 suggests, the effect of instructional resources now disappears from all countries but 
Paraguay. Instead, we observe a significant association between ownership and parent-teacher interaction in all countries but Guatemala. In fact, neither the coefficient for resources nor ownership is significant for this country. However, when I interact school ownership with resources for Guatemala, I find that private school slope on the effect of resources is significantly steeper meaning in more resourceful private schools parents tend to interact with teachers more than that of public schools ${ }^{3}$. This means rich private schools have a more stimulative environment for parents to communicate with teachers in the country. The interaction effect is, however, not significant for other countries (Table A5 in the appendix). The results overall correspond to my assumption that school ownership plays a significant mediating role.

This is to note that the percentage of private schools is quite low in Cambodia, Senegal and Zambia constituting less than 10 percent. Whereas in Ecuador the percentage is 21 percent, in Guatemala 43 percent, in Honduras 39 percent and in Paraguay it is 24 percent. One may argue that the effect of private schools may be led by the unequal distribution of private schools. However, the results hold consistent in all seven countries regardless of the size of school ownership categories even after controlling for all the relevant background information. This indicates the robustness of the findings across different continents and the importance of feepaying schools in encouraging parents' interaction with teachers, which conforms with my initial hypothesis. Furthermore, I conduct different robustness checks to examine whether there is any multicollinearity, especially among resources, ownership and SES but do not find such an indication. ${ }^{4}$ 


\section{Figure 2}

The coefficient plot from OLS regression results on the determinants of parent-teacher interaction

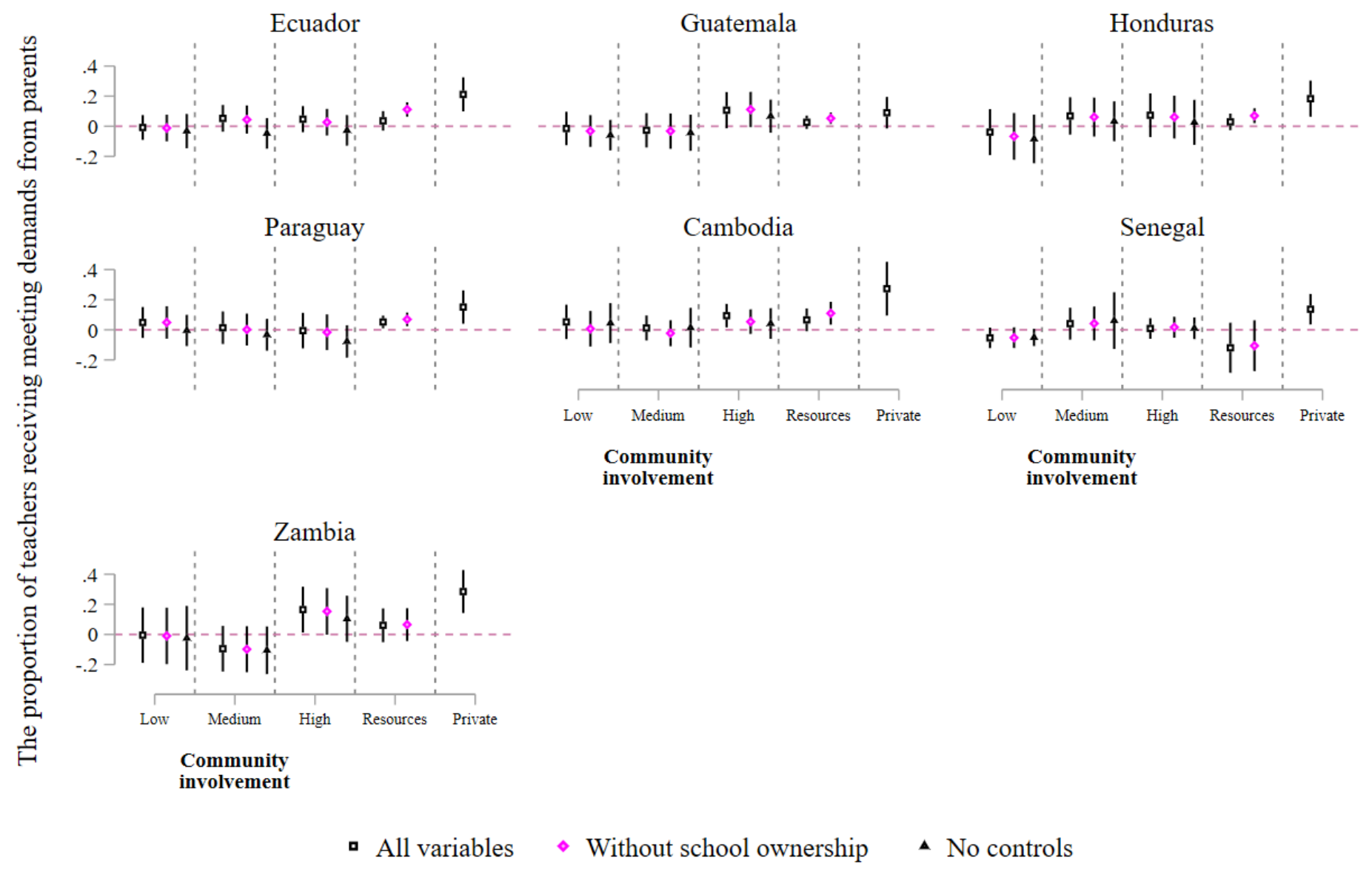

Notes. Controls in the final 'all variables' model include students' SES, grades, sex and maths achievement; school location (urban/rural), teacher-student ratio; teachers' leadership, supportive relationship with students, years of experience, and job satisfaction; and dummies for imputed missing data indicating whether imputed or not.

Source. Author's calculations based on OECD (2015b) 
It is noteworthy to mention that after including ownership in 'all variables' model, the coefficient for the high level of community involvement is now significant for Cambodia and Zambia. However, the coefficients for this variable in all other countries and for the other two categories - medium and low — in these two countries still remain non-significant. Thus, based on the evidence from most country cases, the findings correspond to my initial hypothesis that parentteacher meetings do not depend much on which schools involve communities in different activities. Additionally, as the detailed results presented in Table A4 in the appendix demonstrate, the relationship between SES and parent-teacher interaction remains mostly insignificant. When all other factors controlled, it appears only significant in Cambodia. This could be perhaps parents from various social strata have access to well-resourced schools as there are many low-fee schools in developing countries where pupils from both better-off and disadvantaged backgrounds attend, not just middle class and elites (Srivastava, 2007). As mentioned in section 4.3, I also run GLM models with logit link function to see whether the results are driven by the values of the dependent variable in a proportion that strictly range between 0 and 1 . I find quite similar results for all countries and covariates by GLM estimations as shown in Figure A2 in the appendix. However, I present OLS results in the main analysis as coefficients are better interpretable in this way alongside providing the same results. In the following section, I discuss whether the association of school resources and ownership with parent-teacher interaction varies by parents' SES.

\subsection{Does SES moderate the effect of school ownership and resources?}

As shown in the interaction effects in Table 1, the moderation effect is not significant in the case of school ownership. In other words, the relationship between parent-teacher and SES remains the same in both private and public schools in all seven countries. However, the 
interaction effect for school resources is mixed, that is, it is significant in only three countries. In Guatemala, Honduras and Senegal, the SES slope on parent-teacher interaction gets steeper with every unit increase in instructional resources. But the slope remains unchanged in the other four countries.

This points out the importance of instructional resources, although not in all countries, which particularly attract higher-SES parents enabling them to interact with teachers. In other words, between-school inequality of resources plays a key role in segregating higher- and lowerSES parents in different schools. The combination of higher resources and wealthier parents create a more congenial environment for engagement with teachers. This finding closely corresponds to Cashman and colleagues' (2021) study from rural India where wealthier parents are more likely to involve in children's learning, especially for low-achieving pupils.

However, as the other four country cases suggest, the moderation effect of SES may be context dependent. School resources may not be the only enabling factor for parents from different SES groups to involve in children's learning. Due to limited context-specific variables, it is beyond the scope of this paper to explore the mechanisms of the interaction between SES and school resources for parental-teacher communication. Future research can examine this issue using comparative country cases. 


\section{Table 1}

The interaction effect of SES and instructional resources, as well as school ownership, on the level of parent-teacher interaction

Dependent variable: Parent-teacher meeting demand on students' progress

\begin{tabular}{lrrrrrrr}
\hline & Ecuador & Guatemala & Honduras & Paraguay & Cambodia & Senegal & Zambia \\
\hline SES & 0.028 & $-0.095^{*}$ & $-0.12^{* *}$ & -0.093 & 0.03 & $-0.18^{* *}$ & 0.0065 \\
& 0.079 & 0.04 & 0.045 & 0.054 & 0.061 & 0.056 & 0.057 \\
Instructional resources & 0.032 & $0.051^{*}$ & $0.054^{*}$ & $0.062^{* *}$ & 0.054 & -0.013 & 0.066 \\
& 0.031 & 0.021 & 0.023 & 0.022 & 0.044 & 0.044 & 0.056 \\
Private (ref. Public) & $0.21^{* *}$ & 0.076 & $0.19^{* *}$ & $0.15^{* *}$ & $0.27 * *$ & 0.067 & $0.27 * * *$ \\
& 0.06 & 0.055 & 0.062 & 0.059 & 0.095 & 0.04 & 0.079 \\
SES $\times$ Instructional resources & -0.0078 & $0.021^{*}$ & $0.031 * *$ & 0.021 & -0.0048 & $0.055^{* *}$ & 0.0013 \\
& 0.019 & 0.01 & 0.012 & 0.013 & 0.015 & 0.016 & 0.015 \\
SES $\times$ Private & 0.0018 & -0.0086 & 0.0051 & 0.016 & 0.0043 & -0.017 & 0.00085 \\
& 0.035 & 0.019 & 0.022 & 0.026 & 0.025 & 0.016 & 0.031 \\
Controls & Yes & Yes & Yes & Yes & Yes & Yes & Yes \\
Constant & 0.0059 & $0.29 *$ & $0.39 * *$ & 0.0055 & -0.16 & 0.55 & 0.25 \\
& 0.17 & 0.13 & 0.14 & 0.13 & 0.15 & 0.29 & 0.25 \\
N-students & 5204 & 4430 & 4148 & 3512 & 4860 & 4581 & 3769 \\
N-schools & 158 & 165 & 188 & 162 & 159 & 142 & 170
\end{tabular}

Standard errors in italics $* \mathrm{p}<0.05 * * \mathrm{p}<0.01 * * * \mathrm{p}<0.001$

Notes. The models control for community involvement, students' grades, sex and maths achievement; school location (urban/rural), teacherstudent ratio; teachers' leadership, supportive relationship with students, years of experience, and job satisfaction; and dummies for imputed missing data indicating whether imputed or not.

Source. Author's calculations based on OECD (2015b) 


\section{Discussion and conclusion}

In the late 1990s, 80 percent of developing and emerging economies in different regions were experimenting with decentralisation triggered by the World Bank and other external partners and donors (Manor, 1999). This has become a worldwide movement regardless of the institutional characteristics of countries such as democratic and authoritarian regimes. In the education sector, the common types of 'lowering the bureaucracy' management model have included the promotion of school-based management and community involvement in school decision-making processes. At the dawn of widely implementing educational decentralisation projects, Winkler (1989) argues in a paper commissioned by the World Bank that the aims of decreasing centralisation are mainly: i) mobilising local finances for meeting increasing costs; ii) increasing efficiency and effectiveness; and iii) redistribution of political power by promoting inclusive and democratic decisions. The last point indicates that that decentralisation at the school and local levels aims to include parents and local stakeholders from every spectrum of society in school decisions.

While the main target was to share the cost of education, like other services, with local communities and lessen the burden on the central government, decentralisation has later become a global agenda as a panacea for improving learning achievement and addressing social inequalities through a participatory governance mechanism (Barrera-Osorio et al., 2009). However, little has been discussed to what extent it is more important than sufficient resource distribution. Importantly, it has not been clear how exactly involving communities in school will improve parents' interaction with teachers, which supposedly helps improve children's learning.

In this study, I investigate this research puzzle to determine the relationship between community engagement and parent-teacher interaction to discuss children's progress in seven developing countries. I find that the relationship between these two elements is non-significant in 
most cases. It is rather school ownership that strongly predicts the frequency of parents' meeting requests in six out of seven selected countries. Although there appears to be a significant effect of instructional resources, it vanishes in six out of seven countries when I add ownership to the analysis suggesting a strong mediating effect of this variable. This is probably because paying fees entitles parents more to interact with teachers to ask about children's progress. Similarly, it may mean that lower-SES parents in public schools may not have sufficient knowledge capital to raise their voice because of lack of education. They may not also have enough time to spend visit schools and meet teachers because of longer working hours or necessity to take up multiple jobs. Cashman et al. (2021) suggest that wealthier parents involve more in children's learning in rural India which includes visiting schools and knowing the teacher's name.

However, the higher congregation of high-SES parents in schools does not mean the more interaction with teachers since the SES coefficient is mostly insignificant. As already mentioned, this could be because due to the mushrooming of low-fee private schools in developing countries, comparatively well-resourced private schools have also become more accessible to low-income students (Srivastava, 2007).

I also observe that SES plays a moderating role in the relationship between instructional resources and parental engagement with teachers in three countries. It means while the average effect of resources is not significant, its effect varies by wealth level as higher-SES may be more capable of sending their children to wealthier schools which enables them to interact with teachers that are presumably more experienced and, consequently, more student-friendly. However, evidence from at least four countries suggests no differing effect of school resources by SES level. This indicates that this issue requires more attention in future research identifying the mechanisms 
of how school resources may capacitate parents from different background in low-income contexts.

While this research is not experimental, the correlational findings from a range of developing countries from three continents already show that community involvement does not necessarily mean more positive outcomes. Which hold constant in different models suggesting that the implementation of these institutional reforms should not be taken for granted regardless of contexts and assumed that these will bring better outcomes everywhere. It is also time to think about whether sufficient funding should be a less prioritised issue as Barrera-Osorio et al. (2009) and others expressed the same line of thinking. Contrary to that, Rose (2003) raises concerns about the consequences of leaving education service in the hand of communities rather than the government.

This study offers two broad policy implications. First, community involvement in schools has been a major policy focus in the education sector of developing countries triggered by Washington Consensus and SAP. This is to fund education in an alternative way with the support of communities and to cut the government budget in public education. The ultimate goal is to improve educational outcomes by engaging parents in the students' learning process. However, as this study suggests, the relationship between these two factors is largely insignificant. Private schools and in some cases SES and instructional resources seem to matter more for parents' engagement. Here, private schools, which requires paying fees, is also equivalent to having greater personal and school resources. Thus, leaving education in the hands of local communities may be detrimental to achieving greater social justice as resourceful individuals can access better schools which stimulate parental involvement. As Essuman and Akyeampong (2011) contend, only the say of those who have 'high social standing' and are perceived 'knowledgeable' matters in SMC in 
Ghana. This shows how exclusionary the idea and practice of community involvement alone can be.

Second, corruption in the forms of nepotism and clientelist politics has a rampant presence in the school management system in many developing countries. This means lower-SES parents are more likely to get exploited because of lacking appropriate informational and social capitals. For instance, on a survey in Senegal conducted in 2010, only 30 percent of parents indicated that the decision-making process is transparent in SMCs and parent-teacher associations (PTAs). Moreover, 79 of percent parents in the country paid illegal registration fees, which was also common in other countries in sub-Saharan and Northern Africa (Transparency International, 2010). As pointed out earlier, Joshi (2014) similarly finds that parents are reluctant to send their children to public schools in Nepal because of excessive interference of local politicians in the school management which negatively influence the learning environment. These examples demonstrate that lower-SES parents would be severely disadvantaged to raise their voice by the presence of different forms of corruption in SMCs. The existence of an SMC does not guarantee that the decision-making process is going to be inclusive addressing the learning progress of children.

\subsection{Limitations and the way forward}

The study has several limitations. First, as mentioned, the paper is based on an observational design, but results remain similar even after controlling for relevant factors across countries. Second, while this study accounts for the background of schools, teachers and students, it does not extend exploring the contextual factors that may explain the non-significant association between the two main factors. For instance, parent-teacher interaction may look different in different countries shaped by contextual elements ranging from corruption and nepotism in the 
form of patron-client relationship in school committees to different forms of schools which may have different institutional arrangements for parental involvement.

Moreover, the pre-existing structure of communities can influence their participation in school decisions. To exemplify, in a conflict-prone location or neighbourhood, the weaker base of community solidarity may lead to less involvement of its members in school meetings due to lack of trust (Shibuya, 2020). Future research can explore the mechanisms of parent-teacher communication in comparative contexts using causal design.

The third point is related to the construction of the outcome and the main explanatory variable. As shown in Table A2 in the appendix, some of the disaggregated eight indicators of the community involvement are skewed in some countries. A similar scenario is observed in the case of parent-teacher meeting demand variable as explained in section 4. Although the variables are reconstructed, one may still question that the skewness may be driving the findings. However, I find the results fairly similar in the analyses with both disaggregated and reconstructed new variables $^{5}$. Besides, because of the limited set of variables, the study cannot further explore more dimensions of community involvement which may be relevant to predicting parent-teacher interaction. But, as I explain in section 4, these indicators reflect the focus of international organisations on the wholistic aspects of community engagement in schools. Future research can address these issues with more comprehensive measures of community involvement. 


\section{Endnote}

1. One may argue that parents whose children poorly perform may demand meetings more frequently. However, this issue is not mentioned in the PISA-D questionnaire. To address this, I inspect the relationship between maths achievement and parent-teacher interaction and found that there is a weak correlation. In addition, I control for achievement scores in the analytical models to account for students' ability which may be associated with parents' demand for meetings.

2. Teacher-level variables cannot be merged as teacher id is different from that of students. To take the school mean, I use school weight which means all schools were equally considered to select the sample of teachers.

3. This research does not explore further why such relationship may exist in a particular case due to limited contextual information as also reported in the limitation section in 6.1.

4. I examine the variance inflation factor (VIF) after running the regression models and find that the resulting values are quite small that do not suggest any multicollinearity.

5. The regression results using the disaggregated community involvement variables are not presented in the paper since they consistently show similar results to the reconstructed indicator, but available upon request. 


\section{APPENDIX}

Table A1

Descriptive statistics

Variables

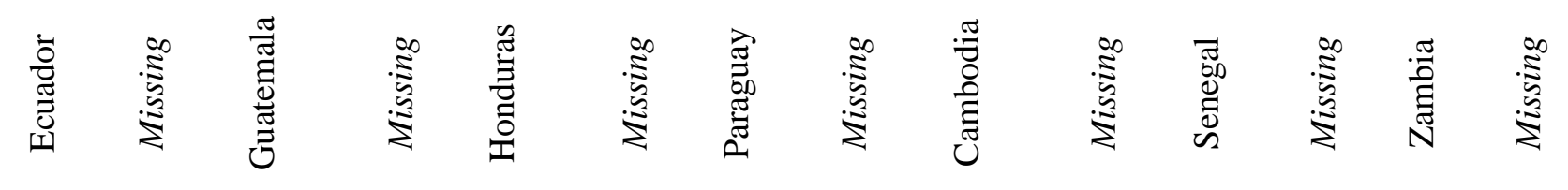

\begin{tabular}{|c|c|c|c|c|c|c|c|c|c|c|c|c|c|c|}
\hline $\begin{array}{l}\text { Parent-teacher meeting demand } \\
\text { received by } \% \text { of teachers }\end{array}$ & 0.61 & - & 0.73 & - & 0.56 & - & 0.49 & - & 0.32 & - & 0.23 & - & 0.56 & - \\
\hline $\mathrm{SD}$ & 0.24 & & 0.25 & & 0.35 & & 0.26 & & 0.26 & & 0.18 & & 0.32 & \\
\hline \multicolumn{15}{|l|}{ Community involvement level (\%) } \\
\hline High & 0.35 & - & 0.57 & - & 0.46 & - & 0.41 & - & 0.20 & - & 0.42 & - & 0.28 & - \\
\hline Medium & 0.21 & & 0.17 & & 0.15 & & 0.23 & & 0.15 & & 0.22 & & 0.14 & \\
\hline Low & 0.26 & & 0.17 & & 0.23 & & 0.23 & & 0.25 & & 0.17 & & 0.34 & \\
\hline No & 0.18 & & 0.09 & & 0.16 & & 0.13 & & 0.40 & & 0.19 & & 0.24 & \\
\hline Instructional resources (mean) & 4.56 & - & 4.35 & 0.01 & 4.22 & 0.02 & 4.47 & - & 4.09 & - & 3.61 & 0.01 & 3.80 & 0.02 \\
\hline SD & 0.76 & & 0.96 & & 1.08 & & 0.97 & & 0.58 & & 0.58 & & 0.57 & \\
\hline Private school $(\%)$ & 0.21 & 0.05 & 0.43 & 0.17 & 0.39 & 0.09 & 0.24 & 0.06 & 0.07 & - & 0.09 & 0.06 & 0.04 & 0.04 \\
\hline Urban school (\%) & 0.68 & - & 0.50 & - & 0.55 & - & 0.48 & - & 0.38 & - & 0.55 & - & 0.29 & - \\
\hline Student-teacher ratio & 22.8 & - & 24.9 & - & 24.3 & - & 24 & - & 30.3 & - & 31.3 & - & 35.9 & - \\
\hline $\mathrm{SD}$ & 6.31 & & 14.72 & & 11.80 & & 20.91 & & 19.58 & & 18.06 & & 21.6 & \\
\hline Teacher leadership capacity & 0.28 & - & 0.60 & 0.01 & 0.48 & 0.01 & 0.53 & - & 0.17 & - & 0.45 & 0.01 & 0.26 & 0.02 \\
\hline $\mathrm{SD}$ & 0.57 & & 0.74 & & 0.83 & & 0.47 & & 0.38 & & 0.60 & & 0.52 & \\
\hline Teacher-student relationship & 6.68 & 0.03 & 6.83 & 0.04 & 7.00 & 0.07 & 6.69 & 0.08 & 6.07 & 0.03 & 6.43 & 0.06 & 6.04 & 0.15 \\
\hline $\mathrm{SD}$ & 1.95 & & 2.07 & & 2.18 & & 2.00 & & 1.64 & & 1.97 & & 2.01 & \\
\hline Teachers' years of experience & 7.71 & - & 7.37 & 0.02 & 8.53 & 0.04 & 11.24 & - & 10.00 & - & 6.35 & 0.01 & 5.37 & 0.03 \\
\hline $\mathrm{SD}$ & 3.96 & & 3.82 & & 5.11 & & 3.79 & & 4.56 & & 2.44 & & 2.69 & \\
\hline Teachers' job satisfaction & 0.90 & - & 1.00 & 0.01 & 0.95 & 0.01 & 0.47 & - & 0.15 & - & -0.24 & 0.01 & -.10 & 0.02 \\
\hline $\mathrm{SD}$ & 0.51 & & 0.57 & & 0.75 & & 0.50 & & 0.46 & & 0.62 & & 0.61 & \\
\hline SES & -.94 & 0.02 & -1.32 & 0.04 & -1.26 & 0.05 & -1.20 & 0.1 & -1.92 & 0.05 & -1.72 & 0.13 & -1.4 & 0.16 \\
\hline
\end{tabular}


SD

Maths scores (mean) $\mathrm{SD}$

Female (\%)

Grades (\%)

7

8

9

10

11

12

$\mathrm{N}$-students

$\mathrm{N}$-schools

$\begin{array}{ccccc}1.15 & & 1.21 & & 1.29 \\ 377 & - & 337.96 & - & 346.3 \\ 75.6 & & 66.62 & & 76.64 \\ 0.49 & - & 0.48 & - & 0.54 \\ & & & & \\ 0.01 & - & .013 & - & 0.07 \\ 0.03 & & .024 & & 0.14 \\ 0.1 & & 0.47 & & 0.38 \\ 0.54 & & 0.15 & & 0.38 \\ 0.31 & & 0.005 & & 0.02 \\ 0.01 & & - & & - \\ 5664 & & 5100 & & 4773 \\ 158 & & 165 & 188\end{array}$

1.12
331.3
66.25
0.51
0.02
0.07
0.22
0.64
0.04
0.001
4510
162

1.12

1.10

1.33

1.33

Notes. SD stands for standard deviation. $\%$ is in percentage points.

Source. Author's calculations based on OECD (2015b) 


\section{Table A2}

Descriptive statistics of parent-teacher interaction and community involvement indicators

$$
\text { Ecuador Guatemala Honduras Paraguay Cambodia Senegal Zambia }
$$

Parent-teacher meeting demand received by $\%$ of teachers

$\begin{array}{llllllll}\text { Never or almost never } & 0.25 & 0.14 & 0.27 & 0.33 & 0.44 & 0.46 & 0.30 \\ \text { Sometimes } & 0.36 & 0.47 & 0.40 & 0.43 & 0.47 & 0.40 & 0.58 \\ \text { Often } & 0.21 & 0.23 & 0.20 & 0.15 & 0.07 & 0.12 & 0.10 \\ \text { Always or almost always } & 0.19 & 0.16 & 0.13 & 0.10 & 0.02 & 0.03 & 0.03\end{array}$

Community involvement...

Build school facilities

$\begin{array}{lccccccc}\text { Yes } & 0.07 & 0.08 & 0.20 & 0.27 & 0.49 & 0.33 & 0.60 \\ \text { No } & 0.93 & 0.92 & 0.80 & 0.73 & 0.51 & 0.67 & 0.40 \\ \begin{array}{l}\text { Maintain school facilities } \\ \text { Yes }\end{array} & 0.25 & 0.15 & 0.21 & 0.24 & 0.48 & 0.21 & 0.49 \\ \text { No } & 0.75 & 0.85 & 0.79 & 0.76 & 0.52 & 0.79 & 0.51 \\ \text { Maintain school grounds and fences } & & & & & & & \\ \text { Yes } & 0.38 & 0.19 & 0.31 & 0.28 & 0.68 & 0.22 & 0.14 \\ \text { No } & 0.62 & 0.81 & 0.69 & 0.72 & 0.32 & 0.78 & 0.86\end{array}$

Construct, maintain or repair furniture or equipment

$\begin{array}{llllllll}\text { Yes } & 0.28 & 0.21 & 0.27 & 0.19 & 0.39 & 0.22 & 0.31 \\ \text { No } & 0.72 & 0.79 & 0.73 & 0.81 & 0.61 & 0.78 & 0.69\end{array}$

Teach when teachers are absent

Yes

$0.05 \quad 0.08 \quad 0.06$

$\begin{array}{llll}\text { No } & 0.95 & 0.92 & 0.94\end{array}$

$\begin{array}{lllll}0.06 & 0.03 & 0.07 & 0.04 & 0.01\end{array}$

Assist teachers in addressing disability needs

$\begin{array}{llllllll}\text { Yes } & 0.29 & 0.09 & 0.16 & 0.07 & 0.25 & 0.14 & 0.33 \\ \text { No } & 0.71 & 0.91 & 0.84 & 0.93 & 0.75 & 0.86 & 0.67\end{array}$

Organise sport activities or school trips

$\begin{array}{llllllll}\text { Yes } & 0.36 & 0.19 & 0.34 & 0.28 & 0.39 & 0.19 & 0.19 \\ \text { No } & 0.64 & 0.81 & 0.66 & 0.72 & 0.61 & 0.81 & 0.81\end{array}$

Assist with preparation and distribution of school meals

$\begin{array}{lrrrrrrr}\text { Yes } & 0.13 & 0.03 & 0.25 & 0.11 & 0.08 & 0.12 & 0.12 \\ \text { No } & 0.87 & 0.97 & 0.75 & 0.89 & 0.92 & 0.88 & 0.88 \\ \text { N- teachers } & 2297 & 1430 & 638 & 1928 & 3894 & 1161 & 873\end{array}$

Source. Author's calculations based on OECD (2015b) 


\section{Figure A1}

Coefficient plot from OLS regression results on the determinants of parent-teacher interaction without imputation dummies

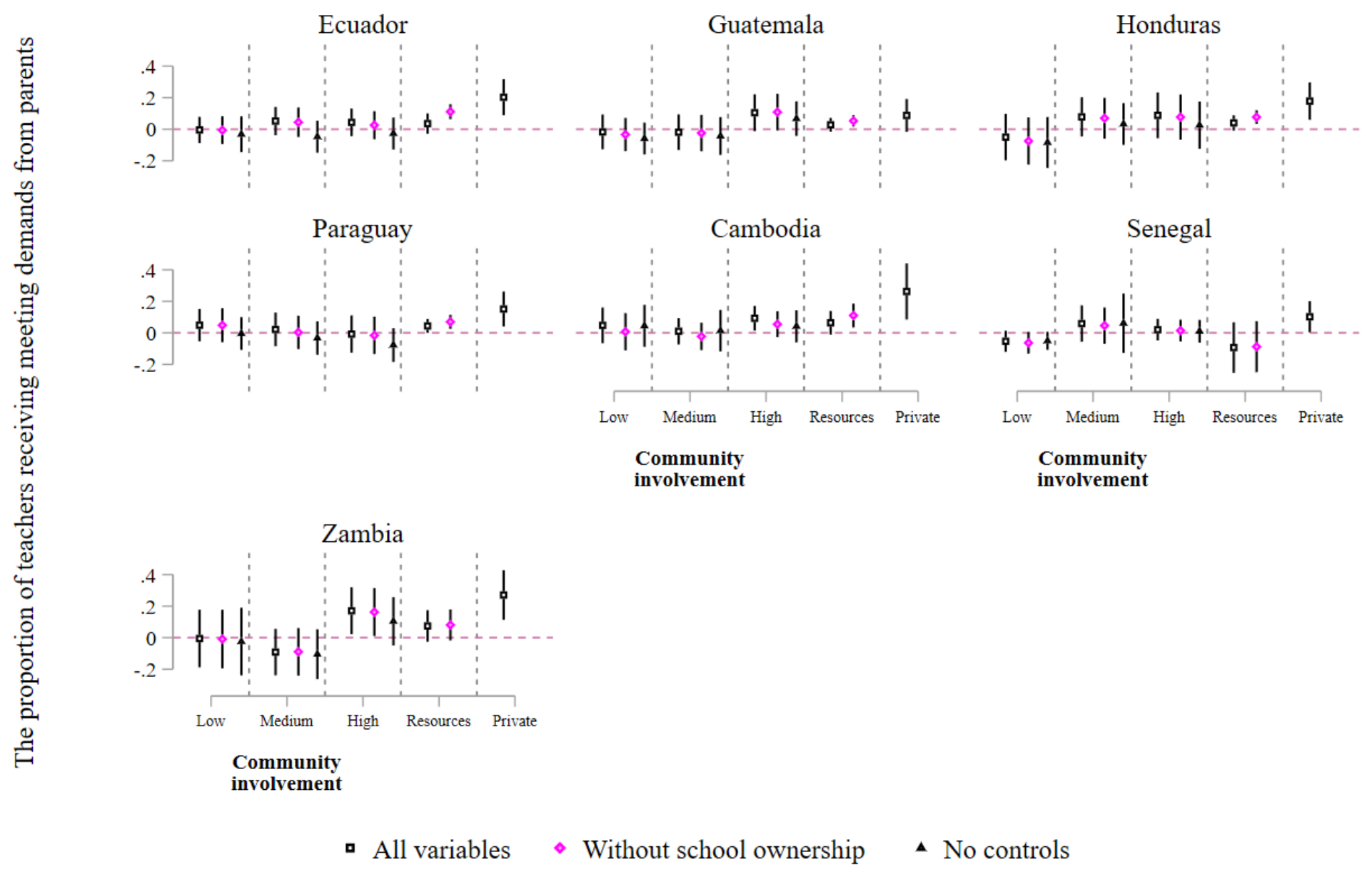

Notes. Controls in the final "All variables" model include students' SES, grades, sex and maths achievement; school location (urban/rural), teacher-student ratio; teachers' leadership, supportive relationship with students, years of experience, and job satisfaction.

Source. Author's calculations based on OECD (2015b) 


\section{Table A3}

The determinants of parent-teacher interaction when school ownership is not added

\begin{tabular}{lrrrrrrr}
\multicolumn{7}{c}{ Dependent variable: Parent-teacher meeting demand on students' progress } \\
\hline & \multicolumn{1}{c}{ Ecuador } & Guatemala & Honduras & Paraguay & Cambodia & Senegal & Zambia \\
\hline Community involvement Level (ref. No) & -0.011 & -0.032 & -0.067 & 0.048 & 0.0069 & -0.052 & -0.0098 \\
Low & 0.045 & 0.053 & 0.079 & 0.055 & 0.06 & 0.035 & 0.095 \\
Medium & 0.045 & -0.032 & 0.061 & 0.0012 & -0.023 & 0.042 & -0.098 \\
& 0.047 & 0.059 & 0.066 & 0.054 & 0.044 & 0.057 & 0.077 \\
High & 0.027 & 0.11 & 0.061 & -0.016 & 0.054 & 0.017 & 0.15 \\
& 0.045 & 0.059 & 0.072 & 0.06 & 0.041 & 0.035 & 0.078 \\
Instructional resources & $0.11^{* * *}$ & $0.053^{* *}$ & $0.070^{* *}$ & $0.069^{* *}$ & $0.11^{* *}$ & -0.11 & 0.065 \\
Urban (ref. Rural) & 0.024 & 0.019 & 0.025 & 0.023 & 0.038 & 0.085 & 0.055 \\
& -0.0088 & -0.04 & -0.1 & -0.0072 & 0.054 & -0.034 & $0.21 * *$ \\
Student-teacher ratio & 0.038 & 0.042 & 0.057 & 0.043 & 0.04 & 0.037 & 0.07 \\
Teacher leadership & -0.00013 & 0.00093 & -0.0034 & 0.0015 & 0.001 & 0.00097 & 0.0016 \\
& 0.003 & 0.0013 & 0.0019 & 0.0012 & 0.00086 & 0.00086 & 0.0012 \\
Teacher-student relationship & -0.013 & 0.054 & -0.064 & 0.018 & $0.25 * * *$ & 0.036 & -0.036 \\
& 0.039 & 0.045 & 0.045 & 0.055 & 0.056 & 0.03 & 0.051 \\
Teachers' years of experience & 0.0026 & 0.0056 & -0.0039 & -0.0022 & -0.0011 & 0.0051 & -0.0075 \\
& 0.0027 & 0.0029 & 0.0036 & 0.0034 & 0.0022 & 0.0027 & 0.0052 \\
Teachers' job satisfaction & $-0.0097 *$ & 0.0015 & -0.011 & -0.00035 & -0.0052 & 0.0036 & 0.0043 \\
& 0.0045 & 0.0043 & 0.0055 & 0.0057 & 0.0036 & 0.0064 & 0.0073 \\
SES & $0.13 * *$ & 0.058 & $0.14^{* * *}$ & 0.073 & -0.063 & $0.11^{* *}$ & $0.087 *$ \\
Female students (ref. Male) & 0.043 & 0.057 & 0.04 & 0.05 & 0.057 & 0.038 & 0.043 \\
& -0.0013 & -0.0054 & $0.019 *$ & 0.0072 & $0.016^{* *}$ & $0.014 * *$ & 0.014 \\
& 0.0083 & 0.0067 & 0.0088 & 0.0072 & 0.0053 & 0.0052 & 0.0097 \\
& $-2.7 \mathrm{E}-05$ & 0.00019 & $0.00037 *$ & $0.00036 *$ & $0.00017 *$ & 0.000098 & 0.00026 \\
& 0.00012 & 0.00016 & 0.00018 & 0.00014 & 0.000084 & 0.00007 & 0.00019 \\
& -0.023 & 0.014 & 0.014 & $0.021 *$ & 0.0075 & -0.0016 & 0.0083
\end{tabular}


Grade level (ref. 7)

$\begin{array}{rrrrrrr}0.012 & 0.013 & 0.015 & 0.0087 & 0.0066 & 0.0055 & 0.015 \\ & & & & & & \\ 0.047 & 0.023 & -0.046 & 0.017 & -0.031 & -0.015 & -0.059 \\ 0.047 & 0.022 & 0.034 & 0.045 & 0.03 & 0.022 & 0.039 \\ 0.026 & 0.026 & -0.052 & -0.0023 & -0.042 & -0.0075 & -0.054 \\ 0.046 & 0.023 & 0.039 & 0.042 & 0.04 & 0.026 & 0.042 \\ 0.051 & -0.047 & -0.10^{*} & -0.0064 & -0.056 & 0.0056 & -0.074 \\ 0.05 & 0.038 & 0.045 & 0.046 & 0.05 & 0.03 & 0.065 \\ 0.059 & -0.077 & -0.13^{*} & -0.041 & -0.059 & -0.028 & -0.051 \\ 0.053 & 0.051 & 0.063 & 0.049 & 0.052 & 0.058 & 0.1 \\ 0.057 & & -0.0042 & -0.084 & -0.086 & 0.029 & 0.02 \\ 0.069 & & 0.076 & 0.058 & 0.057 & 0.08 & 0.097 \\ \text { No } & \text { No } & \text { No } & \text { No } & \text { No } & \text { No } & \text { No } \\ 0.0059 & 0.29 * & 0.39 * * & 0.0055 & -0.16 & 0.55 & 0.25 \\ 0.17 & 0.13 & 0.14 & 0.13 & 0.15 & 0.29 & 0.25 \\ 5204 & 4430 & 4148 & 3512 & 4860 & 4581 & 3769 \\ 158 & 165 & 188 & 162 & 159 & 142 & 170\end{array}$

$\mathrm{N}$-schools

8

9

10

11

12

Private (ref. Public)

Constant

Standard errors in italics $* \mathrm{p}<0.05 * * \mathrm{p}<0.01 * * * \mathrm{p}<0.001$

Note. The models also control for dummies indicating whether missing values imputed or not.

Source. Author's calculations based on OECD (2015b) 


\section{Table A4}

The determinants of parent-teacher interaction when school ownership is added

\begin{tabular}{|c|c|c|c|c|c|c|c|}
\hline & Ecuador & Guatemala & Honduras & Paraguay & Cambodia & Senegal & Zambia \\
\hline \multicolumn{8}{|c|}{ Community involvement Level (ref. No) } \\
\hline \multirow[t]{2}{*}{ Low } & -0.01 & -0.02 & -0.04 & 0.05 & 0.05 & -0.05 & 0.00 \\
\hline & 0.04 & 0.06 & 0.08 & 0.05 & 0.06 & 0.04 & 0.09 \\
\hline \multirow[t]{2}{*}{ Medium } & 0.05 & -0.03 & 0.07 & 0.01 & 0.01 & 0.04 & -0.10 \\
\hline & 0.05 & 0.06 & 0.06 & 0.06 & 0.04 & 0.05 & 0.08 \\
\hline \multirow[t]{2}{*}{ High } & 0.05 & 0.11 & 0.07 & -0.01 & $0.094 *$ & 0.01 & $0.17 *$ \\
\hline & 0.04 & 0.06 & 0.07 & 0.06 & 0.04 & 0.04 & 0.08 \\
\hline \multirow[t]{2}{*}{ Instructional resources } & 0.04 & 0.03 & 0.03 & $0.052 *$ & 0.07 & -0.12 & 0.06 \\
\hline & 0.03 & 0.02 & 0.03 & 0.02 & 0.04 & 0.08 & 0.06 \\
\hline \multirow[t]{2}{*}{ Private (ref. Public) } & $0.21 * * *$ & 0.09 & $0.18 * *$ & $0.15^{* *}$ & $0.27 * *$ & $0.14 * *$ & $0.28 * * *$ \\
\hline & 0.06 & 0.05 & 0.06 & 0.06 & 0.09 & 0.05 & 0.07 \\
\hline \multirow[t]{2}{*}{ Urban (ref. Rural) } & -0.02 & -0.05 & $-0.11 *$ & -0.02 & 0.06 & -0.05 & $0.19 * *$ \\
\hline & 0.04 & 0.04 & 0.06 & 0.04 & 0.04 & 0.04 & 0.07 \\
\hline \multirow[t]{2}{*}{ Student-teacher ratio } & 0.00 & 0.00 & 0.00 & 0.00 & 0.00 & 0.00 & 0.00 \\
\hline & 0.00 & 0.00 & 0.00 & 0.00 & 0.00 & 0.00 & 0.00 \\
\hline \multirow[t]{2}{*}{ Teacher leadership } & -0.03 & 0.05 & -0.07 & 0.02 & $0.24 * * *$ & 0.06 & -0.05 \\
\hline & 0.04 & 0.04 & 0.04 & 0.05 & 0.05 & 0.03 & 0.05 \\
\hline \multirow[t]{2}{*}{ Teacher-student relationship } & 0.00 & 0.01 & 0.00 & 0.00 & 0.00 & $0.0054^{*}$ & -0.01 \\
\hline & 0.00 & 0.00 & 0.00 & 0.00 & 0.00 & 0.00 & 0.01 \\
\hline \multirow[t]{2}{*}{ Teachers' years of experience } & $-0.0099 *$ & 0.00 & -0.01 & 0.00 & 0.00 & 0.01 & 0.01 \\
\hline & 0.00 & 0.00 & 0.01 & 0.01 & 0.00 & 0.01 & 0.01 \\
\hline \multirow[t]{2}{*}{ Teachers' job satisfaction } & $0.14 * *$ & 0.06 & $0.13 * * *$ & 0.07 & -0.06 & $0.075^{*}$ & $0.090^{*}$ \\
\hline & 0.04 & 0.06 & 0.04 & 0.05 & 0.06 & 0.04 & 0.04 \\
\hline \multirow[t]{2}{*}{ SES } & -0.01 & -0.01 & 0.01 & 0.00 & $0.012 *$ & 0.01 & 0.01 \\
\hline & 0.01 & 0.01 & 0.01 & 0.01 & 0.01 & 0.00 & 0.01 \\
\hline Maths achievement & 0.00 & 0.00 & 0.00 & $0.00028 *$ & 0.00 & 0.00 & 0.00 \\
\hline
\end{tabular}




\begin{tabular}{|c|c|c|c|c|c|c|c|}
\hline & 0.00 & 0.00 & 0.00 & 0.00 & 0.00 & 0.00 & 0.00 \\
\hline \multirow[t]{2}{*}{ Female students (ref. Male) } & $-0.028 *$ & 0.01 & 0.01 & $0.018^{*}$ & 0.01 & 0.00 & 0.01 \\
\hline & 0.01 & 0.01 & 0.02 & 0.01 & 0.01 & 0.01 & 0.01 \\
\hline \multicolumn{8}{|l|}{ Grade level (ref. 7) } \\
\hline \multirow[t]{2}{*}{8} & 0.05 & 0.02 & -0.05 & 0.02 & -0.03 & 0.00 & -0.06 \\
\hline & 0.05 & 0.02 & 0.03 & 0.05 & 0.03 & 0.02 & 0.04 \\
\hline \multirow[t]{2}{*}{9} & 0.03 & 0.03 & -0.05 & 0.00 & -0.04 & 0.00 & -0.06 \\
\hline & 0.05 & 0.02 & 0.04 & 0.04 & 0.04 & 0.02 & 0.04 \\
\hline \multirow[t]{2}{*}{10} & 0.05 & -0.05 & $-0.10^{*}$ & 0.00 & -0.06 & 0.01 & -0.07 \\
\hline & 0.05 & 0.04 & 0.04 & 0.05 & 0.05 & 0.03 & 0.06 \\
\hline \multirow[t]{2}{*}{11} & 0.07 & -0.08 & $-0.13^{*}$ & -0.03 & -0.06 & -0.07 & -0.07 \\
\hline & 0.06 & 0.05 & 0.06 & 0.05 & 0.05 & 0.06 & 0.10 \\
\hline \multirow[t]{2}{*}{12} & 0.07 & & -0.05 & -0.07 & -0.08 & -0.03 & -0.01 \\
\hline & 0.07 & & 0.08 & 0.05 & 0.06 & 0.08 & 0.10 \\
\hline \multirow[t]{2}{*}{ Constant } & 0.30 & $0.35 * *$ & $0.49 * * *$ & 0.04 & -0.06 & 0.51 & 0.26 \\
\hline & 0.19 & 0.12 & 0.14 & 0.12 & 0.14 & 0.28 & 0.25 \\
\hline $\mathrm{N}$-students & 5204 & 4430 & 4148 & 3512 & 4860 & 4581 & 3769 \\
\hline N-schools & 158 & 165 & 188 & 162 & 159 & 142 & 170 \\
\hline
\end{tabular}

Standard errors in italics $* \mathrm{p}<0.05 * * \mathrm{p}<0.01 * * * \mathrm{p}<0.001$

Note. The models also control for dummies indicating whether missing values imputed or not.

Source. Author's calculations based on OECD (2015b) 


\section{Table A5}

The interaction effect of school ownership and instructional resources on the level of parent-teacher interaction

\begin{tabular}{lrrrrrrr} 
& \multicolumn{6}{c}{ Dependent variable: Parent-teacher meeting demand on students' progress } \\
\hline & Ecuador & Guatemala & Honduras & Paraguay & Cambodia & Senegal & Zambia \\
\hline Instructional resources & 0.087 & -0.051 & -0.078 & 0.0072 & 0.063 & -0.15 & 0.061 \\
& 0.047 & 0.037 & 0.07 & 0.042 & 0.039 & 0.091 & 0.057 \\
Private (ref. Public) & $0.78^{*}$ & $-0.42^{*}$ & -0.37 & -0.16 & 0.02 & -0.49 & 0.64 \\
& 0.31 & 0.2 & 0.29 & 0.21 & 0.81 & 0.38 & 0.71 \\
Private $\times$ Instructional & & & & & & & \\
resources & -0.11 & $0.12^{* *}$ & 0.14 & 0.067 & 0.048 & 0.16 & -0.084 \\
& 0.062 & 0.045 & 0.071 & 0.045 & 0.15 & 0.1 & 0.16 \\
Controls & Yes & Yes & Yes & Yes & Yes & Yes & Yes \\
Constant & 0.0059 & $0.29 *$ & $0.39 * *$ & 0.0055 & -0.16 & 0.55 & 0.25 \\
& 0.17 & 0.13 & 0.14 & 0.13 & 0.15 & 0.29 & 0.25 \\
N-students & 5204 & 4430 & 4148 & 3512 & 4860 & 4581 & 3769 \\
N-schools & 158 & 165 & 188 & 162 & 159 & 142 & 170
\end{tabular}

Standard errors in italics $* \mathrm{p}<0.05 * * \mathrm{p}<0.01 * * * \mathrm{p}<0.001$

Notes. The models control for community involvement, students' SES, grades, sex and maths achievement; school location (urban/rural), teacher-student ratio; teachers' leadership, supportive relationship with students, years of experience, and job satisfaction; and dummies for imputed missing data indicating whether imputed or not. Source. Author's calculations based on OECD (2015b) 


\section{Figure A2}

Coefficient plot from GLM regression results on the determinants of parent-teacher interaction

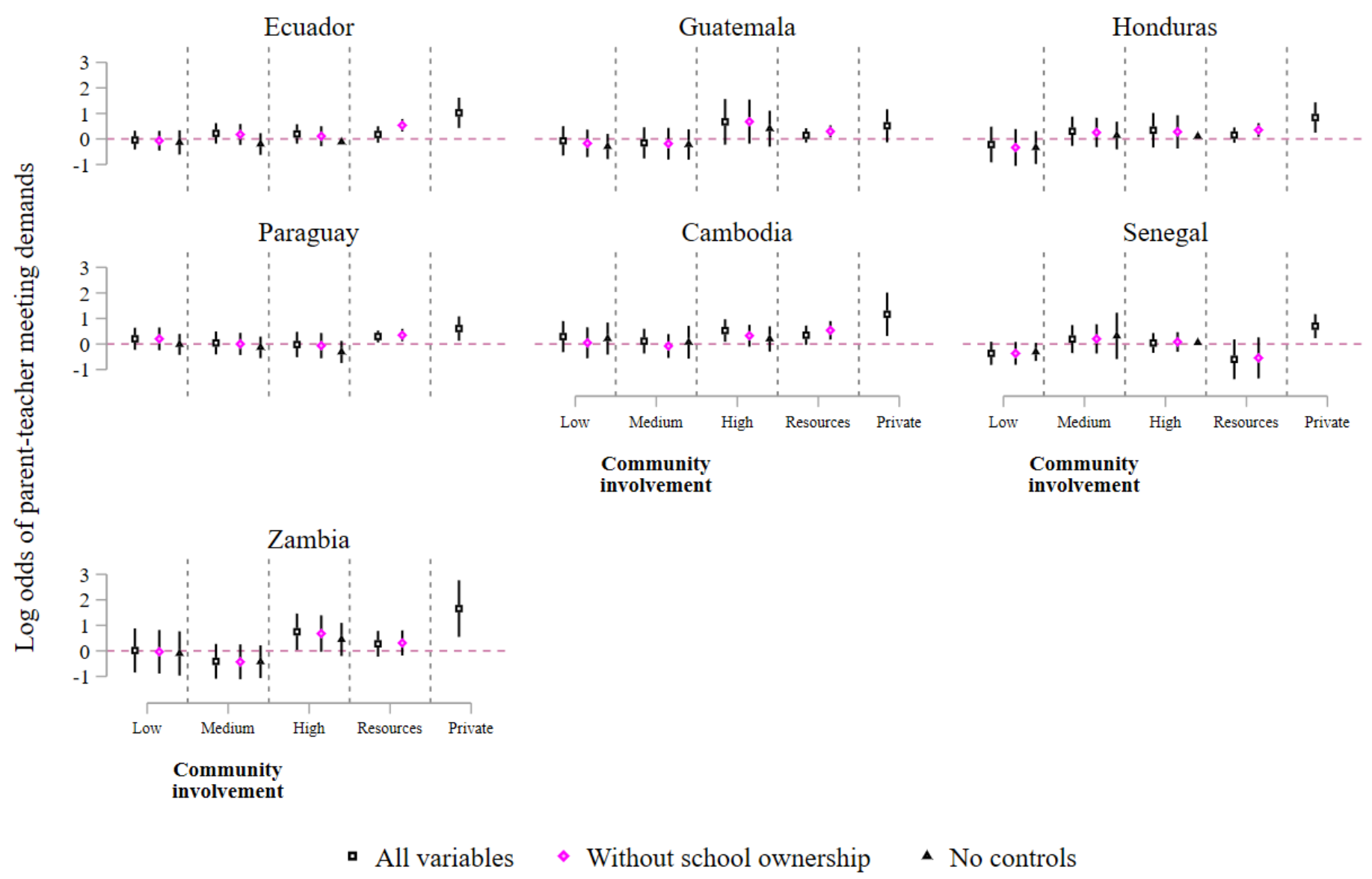

Notes. The models control for community involvement, students' grades, sex and maths achievement; school location (urban/rural), teacher-student ratio; teachers' leadership, supportive relationship with students, years of experience, and job satisfaction; and dummies for imputed missing data indicating whether imputed or not.

Source. Author's calculations based on OECD (2015b) 


\section{References}

Andrews, R., \& Van de Walle, S. (2013). New public management and citizens' perceptions of local service efficiency, responsiveness, equity and effectiveness. Public Management Review, 15(5), 762-783.

Avvisati, F., Gurgand, M., Guyon, N., \& Maurin, E. (2014). Getting parents involved: A field experiment in deprived schools. Review of Economic Studies, 81(1), 57-83.

Ball, S. J., \& Youdell, D. (2009). Hidden privatisation in public education. Education International.

Barnett, E. (2013). An analysis of community involvement in primary schools in Malawi. International journal of educational development, 33(5), 497-509.

Barrera-Osorio, F., Fasih, T., \& Patrinos, H. A. (2009). Decentralized decision-making in schools: The theory and evidence on school-based management. World Bank.

Beck, L. G., \& Murphy, J. (1999). Parental involvement in site-based management: Lessons from one site. International Journal of Leadership in Education, 2(2), 81-102.

Beteille, T. (2009). Absenteeism, transfers and patronage: the political economy of teacher labor markets in India [Doctoral Dissertation, Stanford University]. Stanford, CA.

Briggs, K. L., \& Wohlstetter, P. (2003). Key elements of a successful school-based management strategy. School effectiveness and school improvement, 14(3), 351-372.

Cashman, L., Sabates, R., \& Alcott, B. (2021). Parental involvement in low-achieving children's learning: The role of household wealth in rural India. International Journal of Educational Research, 105, 101701.

Chiu, M. M. (2010). Effects of inequality, family and school on mathematics achievement: Country and student differences. Social Forces, 88(4), 1645-1676. 
Essuman, A., \& Akyeampong, K. (2011). Decentralisation policy and practice in Ghana: the promise and reality of community participation in education in rural communities. Journal of Education Policy, 26(4), 513-527.

Fullan, M., \& Watson, N. (2000). School-based management: Reconceptualizing to improve learning outcomes. School effectiveness and school improvement, 11(4), 453-473.

Ganimian, A. J. (2016). Why do some school-based management reforms survive while others are reversed? The cases of Honduras and Guatemala. International journal of educational development, 47, 33-46.

Gertler, P., Patrinos, H., \& Rubio-Codina, M. (2006). Empowering parents to improve education: Evidence from rural Mexico. World Bank.

Gordon, M. F., \& Louis, K. S. (2009). Linking parent and community involvement with student achievement: Comparing principal and teacher perceptions of stakeholder influence. American journal of education, 116(1), 1-31.

Gruijters, R. J., \& Behrman, J. A. (2020). Learning Inequality in Francophone Africa: School Quality and the Educational Achievement of Rich and Poor Children. Sociology of Education, 0038040720919379.

Hanushek, E. A., Link, S., \& Wöbmann, L. (2013). Does school autonomy make sense everywhere? Panel estimates from PISA. Journal of Development Economics, 104, 212 232.

Heyneman, S. P., \& Loxley, W. A. (1983). The effect of primary-school quality on academic achievement across twenty-nine high-and low-income countries. American Journal of Sociology, 88(6), 1162-1194. 
Islam, A. (2019). Parent-teacher meetings and student outcomes: Evidence from a developing country. European Economic Review, 111, 273-304.

Joshi, P. (2014). Parent decision-making when selecting schools: The case of Nepal. Prospects, 44(3), 411-428.

Kim, S. (2018). Parental involvement in developing countries: A meta-synthesis of qualitative research. International journal of educational development, 60, 149-156.

Kingdon, G. G., Little, A., Aslam, M., Rawal, S., Moe, T., Patrinos, H., Beteille, T., Banerji, R., Parton, B., \& Sharma, S. K. (2014). A rigorous review of the political economy of education systems in developing countries (Final Report. Education Rigorous Literature Review. Department for International Development (UK), Issue.

Kowalczyk, P., \& Jakubczak, J. (2014). New Public Management in Education: From School Governance to School Management. Human Capital without Borders: Knowledge and Learning for Quality of Life.

Leithwood, K., \& Menzies, T. (1998). Forms and effects of school-based management: A review. Educational policy, 12(3), 325-346.

Manor, J. (1999). The political economy of democratic decentralization. The World Bank. Maroy, C. (2009). Convergences and hybridization of educational policies around 'postbureaucratic'models of regulation. Compare, 39(1), 71-84.

Meier, K. J., \& O'Toole Jr, L. J. (2003). Public management and educational performance: The impact of managerial networking. Public administration review, 63(6), 689-699.

Naidoo, J. (2005). Education decentralization in Africa: Great expectations and unfulfilled promises. In A. W. Wiseman \& D. P. Baker (Eds.), Global trends in educational policy. Emerald Group Publishing Limited. 
Nishimura, M. (2017). Community Participation in school management in developing countries. Oxford Research Encyclopedia of Education. https://doi.org/https://doi.org/10.1093/acrefore/9780190264093.013.64

OECD. (2015a). DAC List of ODA Recipients http://www.oecd.org/development/financing$\underline{\text { sustainable-development/development-finance- }}$ $\underline{\text { standards/historyofdaclistsofaidrecipientcountries.htm }}$

OECD. (2015b). PISA for Development https://www.oecd.org/pisa/pisa-for-development/

OECD. (n.d.). PISA for Development Technical Report. https://www.oecd.org/pisa/pisa-fordevelopment/pisafordevelopment2018technicalreport/

Reitzug, U. C., \& Cross, B. E. (1995). Constraining and facilitating aspects of site-based management in urban schools. International Journal of Educational Reform, 4(3), 329340.

Rose, P. (2003). Communities, gender and education: Evidence from sub-Saharan Africa. EFA Global Monitoring Report.

Sahlberg, P. (2010). The secret to Finland's success: Educating teachers. Stanford Center for Opportunity Policy in Education, 2, 1-8.

Shibuya, K. (2020). Community participation in school management from the viewpoint of relational trust: A case from the Akatsi South District, Ghana. International journal of educational development, 76, 102196.

Shoraku, A. (2009). Educational movement toward school-based management in East Asia: Cambodia, Indonesia and Thailand. Background paper prepared for the Education for All Global Monitoring Report. 
Srivastava, P. (2007). For philanthropy or profit? The management and operation of low-fee private schools in India. In P. Srivastava \& G. Walford (Eds.), Private schooling in less economically developed countries: Asian and African perspectives (pp. 153-186).

Routledge.

Tolofari, S. (2005). New public management and education. Policy futures in education, 3(1), 75-89.

Transparency International. (2010). Africa education watch: Good governance lessons for primary education. Transparency International.

Uemura, M. (1999). Community Participation in Education: What do we know? World Bank.

Uljens, M., Wolff, L.-A., \& Frontini, S. (2016). Finland: NPM resistance or towards newwelfarism in education. In H. M. Gunter, E. Grimaldi, D. Hall, \& R. Serpieri (Eds.), New Public Management and the Reform of Education : European lessons for policy and practice (Vol. 39-52, pp. 367). Routledge.

Vavrus, F. (2005). Adjusting inequality: Education and structural adjustment policies in Tanzania. Harvard Educational Review, 75(2), 174-201. https://doi.org/DOI 10.17763/haer.75.2.565v0213145413t5

Vermeulen, W. (2018). Decentralised funding and inequality in education. In J. Kim \& S. Dougherty (Eds.), Fiscal Decentralisation and Inclusive Growth. OECD.

Winkler, D. R. (1989). Decentralization in education: An economic perspective (Vol. 143). World Bank.

World Bank. (2007). Getting parents involved: A field experiment in deprived schools. Review of Economic Studies, 81(1), 57-83.

World Bank. (n.d.-a). Projects \& Operations https://projects.worldbank.org/ 
World Bank. (n.d.-b). World Bank Country and Lending Groups https://datahelpdesk.worldbank.org/knowledgebase/articles/906519-world-bank-countryand-lending-groups

Zajda, J. (2006). Introduction: Decentralisation and privatisation in education: The role of the state. In J. Zajda (Ed.), Decentralisation and privatisation in education (pp. 3-27). Springer. 